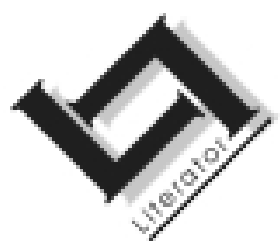

\title{
Nieuwe momenten? De Nederlandse roman na 1985
}

\author{
Eep Francken \\ Opleiding Nederlandse Taal- en Cultuur \\ Universiteit Leiden \\ NEDERLAND \\ E-pos: eepfranc@rullet.leidenuniv.nl
}

\section{Abstract}

New moments? The Dutch novel after 1985

Looking at the years 1985-2000, a few questions about Dutch literature seem to be relevant. Which new Dutch novels were the most successful? Which changes occurred in Dutch society during that same period? And in the literary world of the Netherlands? This article attempts to answer these questions, while at the same time arguing for a new edition of Jacques van der Elst's Momente van die Nederlandse letterkunde (Moments in Dutch literature).

\section{Inleiding}

In Hollandse ogen is professor Jacques van der Elst in de eerste plaats de man van de samenwerking tussen Nederland en Zuid-Afrika. In de jaren tachtig verzette hij zich in Nederland tegen de halve culturele boycot, die maakte dat hem de toegang tot het congres van de Internationale Vereniging voor Neerlandistiek aanvankelijk geweigerd werd. In 1992 organiseerde hij in Potchefstroom het SAVN-congres. Hij slaagde erin een flink aantal bezoekers uit Vlaanderen en Nederland naar het congres te krijgen, en bovendien lukte het hem de Nederlandse Taalunie voor het eerst een actieve rol te laten spelen in Zuid-Afrika. Achteraf is makkelijk in te zien dat vrijwel alles wat sindsdien aan onderlinge samenwerking tot stand is gekomen, zijn wortels heeft in dat congres van Van der Elst en zijn mede-Potchefstromers.

Al veel eerder had hij trouwens het initiatief genomen tot en leiding gegeven aan een ander neerlandistisch project: het literatuurgeschiedenis-achtige Momente van die Nederlandse letterkunde. Hoewel dit werk 
nog altijd van belang is, moet bij deze prestatie van hem inmiddels wel een "maar" klinken. Dat "maar" heeft betrekking op de leeftijd van het boek, inmiddels zo eerbiedwaardig dat de gedachte aan een facelift zich begint op te dringen. Wat is er intussen aan nieuwere Nederlandse literatuur niet allemaal op de markt gekomen? Wat moet er worden toegevoegd, om de Momente nog beter aan Van der Elsts streven te laten beantwoorden? Een begin van een antwoord op die vraag geeft het hier volgende stuk, dat zich vrijwel helemaal beperkt tot Noord-Nederland - en Vlaanderen dus schandelijk verwaarloost, en ook tot slechts één genre: de roman. Maar het probeert wel, die roman te plaatsen in wat breder verband. De mode heerst immers, ook in de literatuurgeschiedschrijving.

In Het leven uit een dag, de roman van A.F.Th. van der Heijden uit 1988, speelt het leven zich af in ongeveer vierentwintig uur. Wie 's ochtends vroeg geboren wordt, gaat om een uurtje of negen naar school, is een paar uur later al volwassen en sterft de volgende ochtend. In de wereld van dit verhaal ontbreekt het volstrekt aan herhalingen - alles doe je hooguit één keer. Een opvallend voorbeeld hiervan vormen liefde en voortplanting: normale mensen worden één keer verliefd, krijgen één keer een kind, zijn dan op elkaar uitgekeken, en in seksueel opzicht meteen ook op alle anderen. Wel komen er opvallend veel drielingen voor, om redenen die makkelijk zijn te begrijpen.

De figuren van deze roman stellen zich een hel en een hemel voor. De gedachte toestand in de hemel is een radicalisering van wat ik al beschreef. Het bestaan is er oneindig kort: alle goeds wordt samengebald in één heerlijke gewaarwording en iedere zweem van herhaling ontbreekt volstrekt. De lezer ziet wel aankomen wat dan de hel zal zijn: inderdaad doet wat wij daarover te horen krijgen sterk denken aan onze eigen vertrouwde wereld, die immers overloopt van herhaling: uur na uur, dag na dag, week na week. Vreselijk!

Ter ere van professor Jacques van der Elst zou ik u, lezer, één heerlijke flits-gewaarwording moeten bezorgen, die $u$ in een ondeelbaar klein moment zou laten kennismaken met alle heerlijkheden van de Nederlandse romankunst van de laatste jaren. Maar in feite is mijn bijdrage eerder te vergelijken met een wandeling door een winkelstraat, die de Nederlandse samenleving moet verbeelden. Het is na sluitingstijd, dus zijn ter bescherming tegen vandalisme alle etalages met metalen rolgordijnen aan het oog onttrokken. Als gids trek ik hier en daar een gordijn op en laat ik u nippen aan wat in enkele van die uitstalkasten te zien is: Nederlandse romans, verschenen na 1985. Maar om te beginnen iets over de straat zelf: de Nederlandse maatschappij en in het bijzonder de literaire wereld, sinds datzelfde jaar. 


\section{Nederland na 1985}

Volgens een veel nageprate opvatting, kort geleden nog verwoord door oud-ambassadeur Niehaus (zie Bootsma, 2000), is Nederland al jarenlang min of meer "af". Alles is goed geregeld, op een paar kleinigheden na. Er verandert dan ook vrijwel niks; we hebben een saai land waar niet of nauwelijks over te schrijven valt en waarvandaan zeker geen nieuwe muziek opschalt. "We" mogen af en toe wel eens een Nobelprijsje winnen, maar nooit die voor literatuur - die gaat eerder naar een land als Zuid-Afrika.

Inderdaad stellen de veranderingen in Nederland gedurende de laatste vijftien jaar weinig voor als men ze gaat vergelijken met die in ZuidAfrika, maar aan de andere kant is er naar Nederlandse maatstaf in ons land sinds 1985 toch juist veel gebeurd en veel veranderd. Europese ontwikkelingen als het verdwijnen van het communisme en de uitbreiding van de Europese Unie zijn voor ons indrukwekkend; met daarnaast de ellendige burgeroorlog en moordpartijen in Joegoslavië, waarbij Nederland direct betrokken is.

Ook binnenslands zijn er naar onze eigen indruk ingrijpende ontwikkelingen, ten dele onder invloed van de economische mondialisering en alweer - de Europese Unie. Men praat van een "liberalisering" van de economie (daar heb je de winkelstraat) waarbij veel meer speelruimte wordt gegeven aan het zakenleven. De staatsbedrijven worden deels verkocht; allerlei regels en regeltjes zijn versoepeld of geschrapt. Zo zijn er veel minder diploma's nodig om één of ander bedrijfje te beginnen en mogen de winkels in de meeste plaatsen langer open blijven, soms zelfs op zondag. De belasting wordt verlaagd, zodat de burgers om de economie aan te jagen meer te besteden krijgen, maar de staat minder. Overheidsuitgaven zijn dan ook jarenlang teruggeschroefd, bijvoorbeeld voor het onderwijs, in het bijzonder voor de universiteiten. De werkloosheid is door dit alles inderdaad teruggelopen, zij het nog lang niet verdwenen; wel is waar dat je dezer dagen bij winkels, cafés en restaurants struikelt over de bordjes waarmee personeel gevraagd wordt, maar ook dat scholen in arme buurten de kinderen af en toe een dag naar huis sturen vanwege gebrek aan onderwijzers.

De optimist roept: "iedereen rijk"; de pessimist spreekt over afbraak van de sociale zorg, overconsumptie en Amerikanisering van de maatschappij. Het staat vast dat zowel de inkomensverschillen als de misdaadcijfers zijn gestegen; hier en daar hoort men spreken over een uit elkaar vallende samenleving. Maar het pleit is nog niet beslecht. Ook de oude zuinige Nederlandse cultuur van "zuinig aan", "eerlijk delen" en "doe maar gewoon, dan doe je gek genoeg", die ons land de rijkste 
armen ter wereld oplevert, bestaat nog. De minister-president rijdt nog altijd bij voorkeur op de fiets naar zijn werk (en laat zich daarbij nog altijd graag "betrappen" door fotografen). Her en der klinken eind 2000 oproepen tot "nieuw burgerschap" en een "nieuwe beschaving", allebei op basis van de traditionele solidariteit. Er heerst dus spanning tussen, aan de ene kant, de opvatting die in kleine verschillen tussen rijk en arm een basis voor de samenleving zoekt, en de laat-twintigste-eeuwse visie van doelgerichtheid, liberalisering en individualisering ("ieder voor zich") aan de andere.

Hoe men over dit alles ook denkt, vast staat dat het Nederland van nu aantrekkelijk is voor buitenlanders. Hun aantal groeit, zodat de Nederlandse samenleving, zeker in de steden, inmiddels een duidelijk multietnisch karakter gaat vertonen. Marokkanen, Turken, Antillianen, vluchtelingen uit alle rampgebieden van de wereld, zij zullen tegen het jaar 2015 zo'n 12\% van de bevolking uitmaken, en in de grote steden de helft (zie Tesser, et al., 1999). Dit is op zichzelf geen probleem, maar het kost wel moeite om de inburgering van de grote aantallen nieuwe uitheemse Nederlanders in behoorlijke banen te leiden. Bij groeiende aantallen binnenkomers verloopt die integratie te langzaam; er dreigt een onderklasse van tweederangsburgers te ontstaan, van wie de kinderen naar slechte scholen gaan, die slecht Nederlands spreken, en hoog scoren in de statistieken voor werkloosheid en misdadigheid (vgl. Scheffer, 2000). Kortom: "in Nederland gebeurt niets" is hooguit een halve waarheid.

\section{De literaire wereld}

Over nieuwe ontwikkelingen in de wereld van het boek is zonder twijfel een nieuw boek vol te schrijven, maar ik signaleer slechts een vijftal ontwikkelingen, waarbij ik de somberste vooropstel. Het gaat dan om de ontlezing: naar verluidt leest er in Nederland bijna niemand meer, en is in het bijzonder boeken lezen alleen nog een activiteit van bejaarden of rare snoeshanen. Klopt het? Leest er in Nederland inderdaad geen hond meer? Hiernaar wordt uiteraard, zoals naar vrijwel alles, voortdurend sociaal-wetenschappelijk onderzoek verricht, waaruit bijvoorbeeld blijkt dat de Nederlander in 1955 nog 2,4 uur per week met zijn neus in een boek zat, maar in 1985 nog maar 1,3 uur (tijdschriften en kranten niet meegeteld). Hoewel dit cijfer voor 1990 weer oploopt naar 1,5 (aldus Knulst \& Kraaykamp, 1996:33, 81), blijkt er met het boeken lezen dus inderdaad wel iets loos te zijn. Gelukkig heeft Anbeek (op grond van cijfers uit hetzelfde onderzoek) gewezen op één bepaalde bevolkingsgroep die niet alleen, tegen alle ontlezingsgeweld in, braaf stand houdt, maar zelfs steeds méér boeken gaat lezen: de goedopgeleide vrouwen, geboren voor 1950. Zij vormen in Nederland de reddingsboei voor de 
literatuur. Dezelfde groep is trouwens sterk oververtegenwoordigd in leeskringen.

Zorg over deze ontlezing wordt luchtig weggewuifd door mensen uit de boekhandel, die meer te maken denken te hebben met een tweede ontwikkeling: die van de vercommercialisering van de boekenwereld. Zij hebben heel andere cijfers tot hun beschikking, die zij veel belangrijker vinden. Zo betoogt Henk Kraima, directeur van het bureau voor de Collectieve Propaganda voor het Nederlandse Boek, volgens NRC Handelsblad (31 januari 2000) dat de bevolking tussen 1938 en 1998 verdubbeld is, maar de boekenverkoop vertwaalfvoudigd (van 3 naar 36 miljoen per jaar). Voor de uitleenbibliotheken brengt hij dan nog een factor 17 in de strijd: van 10 naar 170 miljoen uitgeleende boeken per jaar. Geen enkele reden om moeilijk te doen, vindt Kraima. Maar wie de cijfers naast elkaar zet, moet besluiten dat steeds meer boeken weliswaar gekocht maar niet gelezen worden, en bespeurt een staaltje overconsumptie dat onbehaaglijk stemt.

Andere kanten van de vercommercialisering krijgen overigens meer aandacht. Zo gaat de concentratie in de boekhandel en de uitgeverij, die lang voor 1985 was begonnen, almaar verder. Een paar grote concerns bezitten vrijwel alle uitgeverijen en vrijwel alle boekwinkels. Er bestaan nog wel zelfstandige uitgeverijtjes met een stuk of vijf medewerkers, maar een zelfstandige boekwinkel waar de eigenaar zelf zijn klanten helpt, is tegenwoordig een bezienswaardigheid. Inmiddels heerst er een bestseller-systeem, waarbij een onevenredig deel van de totale verkoop bestaat uit honderdduizenden exemplaren van een klein aantal boeken (de bestsellers), terwijl daarentegen van veel boeken de eerste druk tegen verlaagde prijs in de ramsj belandt. Uitgeverijen móeten bijna wel van tijd tot tijd zo'n bestseller in hun fonds hebben om te overleven, en proberen met grootscheepse reclame en schrijversoptredens, liefst voor de televisie, hun doel te bereiken. Zijn er aangrijpende actualiteiten, dan is iedereen op zoek naar een boek dat op die actualiteit geïnspireerd is. $\mathrm{Na}$ de verschrikkelijke kwestie-Dutroux (de zaak van de vermoorde meisjes in België), was de markt willig voor romans over kindermishandeling. De Chinese immigrante Lulu Wang, die in het spoor van de internationale successchrijfster Jung Chang al eerder hoge oplagen had behaald met een boek over háár lijden onder het Chinese communisme, onthulde vervolgens in een tweede kassakraker dat zij als meisje óók nog seksueel mishandeld was. Hoe de critici, bijvoorbeeld Elsbeth Etty (1999), haar ook verketterden, het deed weinig afbreuk aan de verkoop. Lulu Wangs succes kan men ten dele verklaren doordat zij niet alleen tegen de actualiteit aanschurkt, maar tegelijk tegemoet komt aan het verlangen van de lezer naar "verhalen die echt gebeurd zijn": is 
een boek autobiografisch (of tenminste als zodanig voor te stellen), dan groeit de belangstelling.

Dit blijkt bijvoorbeeld bij de boeken van Connie Palmen, Nederlands populairste filosofe. Nadat zij met haar filosofische roman De wetten (1991) bekend geworden was, volgde: De vriendschap (1995), over een filosofe die de literatuur in wil. Haar derde en tot nu toe grootste succesboek is I.M. (1998), een terugblik op haar leven met de beroemde televisieman Ischa Meijer, tevens haar reactie op zijn vroege dood. Hoewel Palmen een veel serieuzer auteur is dan Lulu Wang, overtreft toch ook bij I.M. het succes aan de toonbank verre dat bij de kritiek. Connie Palmen biedt de kans om over te stappen op een prettiger ontwikkeling in de Nederlandse boekenwereld: die van de internationalisering. In hoeverre het rechtstreeks te maken heeft met het om zich heen grijpende commerciële denken is onduidelijk, maar de Nederlandse regering heeft de laatste jaren veel meer dan voorheen werk gemaakt van een gerichte propaganda voor Nederlandse literatuur in het buitenland, en Palmen hoort tot de vele schrijvers die daarvan hebben geprofiteerd. Het aantal vertalingen uit het Nederlands is vrijwel overal sterk toegenomen, maar vooral in Duitsland, waar iemand als Cees Nooteboom (van wie de belangrijkste boeken dateren van voor 1985) nu tot de literaire reuzen wordt gerekend. Het is allemaal mooi voor het Nederlandse chauvinisme, maar wat belangrijker is: op deze manier krijgen onze auteurs een ruimere kritische reactie op hun werk, van critici uit andere culturen.

Ook voor mijn vierde ontwikkeling biedt Palmen een opstap: die van de vervrouwelijking van de literaire wereld. Ik heb de hoogopgeleide lezeressen (vijftig plus) al gememoreerd, maar de feminisering van de lezersgroep staat niet op zichzelf: vrouwen nemen over het algemeen een groter aandeel in de wereld van het boek. Er is een groeiend aantal succesvolle schrijfsters, zoals Renate Dorrestein, Anna Enquist, Tessa de Loo, Margriet de Moor, Charlotte Mutsaers, Nelleke Noordervliet en Frida Vogels, van wie ook Enquist en De Loo, net als Lulu Wang en Palmen, hun grote oplagen bereiken bij overwegend matige kritiek. De situatie doet denken aan de jaren twintig en dertig, toen M. SchartenAntink, Jo van Ammers-Küller en Ina Boudier-Bakker, ongekroonde koninginnen van de boekhandel, weinig genade vonden bij iemand als Ter Braak. Maar in tegenstelling tot destijds is de geringe lof niet langer te verklaren doordat bijna alle critici man zouden zijn, want ook onder recensenten treden steeds vaker vrouwen op de voorgrond. In het bijzonder springt de vervanging van de literatuurchef van Vrij Nederland, Carel Peeters, in het oog. Ondanks zijn goede reputatie, die hem zelfs een professoraat in de literatuurkritiek had bezorgd, werd hij in 1999 
terzijde geschoven en opgevolgd door Xandra Schutte. Ook in de uitgeverij lijkt het aantal vrouwen op belangrijke posten sterk te groeien.

Tenslotte de multi-culturaliteit van de literaire wereld. Die is tot nu toe vooral merkbaar in de literatuur zelf, al werken er uitheemse Nederlanders in boekhandel en uitgeverij, en al concentreert een uitgever als "In de Knipscheer" zich voor een belangrijk deel op "multiculturele" boeken. Weliswaar is de Nederlandse literatuur in 1997 aangeklaagd vanwege een te laag multiculti-gehalte, toen de Surinaamse essayist en journalist Anil Ramdas, zelf vooraanstaand medewerker van NRC Handelsblad en van de televisie en dus voorbeeldig ingeburgerd, de inheemse auteurs verweet dat in hun boeken nog altijd niet of nauwelijks serieuze personages voorkomen met een uitheemse achtergrond (Ramdas, 1997). De romancier, Joost Zwagerman, die zelf in De buitenvrouw (1994) wel degelijk zo'n serieus personage laat optreden, is bij die gelegenheid voor zichzelf en zijn inheemse collega's opgekomen (vgl. Zwagerman, 1997; Boenink, 1997), maar zijn verdediging was vooral overtuigend voorzover hij over eigen werk schreef en kon de indruk niet wegnemen dat Zwagerman die bekende ene zwaluw van het spreekwoord is. Nu kan men een individuele auteur moeilijk verwijten dat in zijn werk een aspect als multi-culturaliteit ontbreekt: onderwerpskeuze is vrij. Maar Ramdas legt wel de vinger op een reële tweedeling in onze culturele wereld: natuurlijk weet elke Nederlandse schrijver dat er veel uitheemse Nederlanders zijn, maar uit hun kleine rol in de romanwereld blijkt dat zij kennelijk nog niet horen tot het "eigen terrein".

Maar dat neemt niet weg dat de tweedeling op een andere manier wel degelijk bestreden wordt: door het groeiende aantal auteurs uit uitheems-Nederlandse kring. Naast een grote groep schrijvers met speciale banden met de vroegere koloniën beschikt de Nederlandse literatuur inmiddels over uitheemse auteurs van heel andere komaf, van wie er drie genoemd worden in een bericht in Die Burger van 19 april 2000, over hun protest tegen de beslissing van de al genoemde C.P.N.B. om het boekenweekgeschenk voor het jaar 2001 (over een multicultureel thema) voor het eerst in de geschiedenis te laten schrijven door een buitenlander, namelijk door Rushdie. Uitheems-Nederlandse schrijvers als Kader Abdollah, Abdelkadir Benali en Hafid Bouazza voelen zich hierdoor gepasseerd.

Onder de vluchtelingen die naar Nederland zijn gekomen, zijn ook schrijvers. Enkelen proberen over te stappen op het Nederlands; de Iraniër Abdollah is het bekendste voorbeeld. Hij heeft in het Nederlands al een aantal verhalenbundels en een roman geschreven en is columnist van De Volkskrant. Maar zoals te begrijpen valt, is een andere groep veel groter: die van de "tweede-generatie-immigranten". Dit zijn kinderen 
van Turkse en Marokkaanse arbeiders, die jong naar Nederland zijn gekomen of in Nederland zijn geboren, op school en op straat voortreffelijk Nederlands geleerd hebben en nu behoren tot de jonge schrijvers van de Nederlandse literatuur. Benali en Bouazza maken hiervan deel uit, net als de Leidse student Nederlands Said El Haji. Maar zij zijn nog niet bekend genoeg voor het boekenweekgeschenk. De C.P.N.B. heeft in een ver verleden wel gekozen voor jonge opkomende auteurs zoals in 1948 Hella S. Haasse met Oeroeg, maar kiest al jarenlang voor de veilige weg met uitsluitend opdrachten voor gezeten beroemdheden, zoals in 1994 Hella S. Haasse met Transit, en in 2000 Harry Mulisch.

In het werk van de vluchtelingen en de Marokkanen spreken de ervaringen van hun minderheidsgroepen in Nederland, maar gelukkig beperken zij zich al lang niet meer tot realistisch schrijven over dit ene onderwerp, hoe belangrijk ook. Bouazza's debuut, de verhalenbundel De voeten van Abdullah (1996), biedt een mooi voorbeeld van de mogelijkheden en moeilijkheden van de multiculturele schrijver. Bouazza vermengt Arabische elementen, sprookjesmotieven uit Duizend-en-één nacht, met elementen die nadrukkelijk Nederlands zijn. Tot zijn inspiratiebronnen hoort allerlei werk uit de oudere Nederlandse literatuur: de abele spelen uit de middeleeuwen (Lanseloet van Denemarken), de zeventiende-eeuwer Vondel, maar ook iemand als de dichter Geerten Gossaert (1884-1958). Gossaert geldt in Nederland als de meester van het archaïsme, de dichter die bijna uitgestorven Nederlandse woorden opdiept en in zijn poëzie tot nieuw leven weet te wekken. Ditzelfde doet nu Hafid Bouazza: als Marokkaanse prins kust hij de slapende woorden wakker, die geen Nederlander meer kent maar die hij bijvoorbeeld bij Gossaert heeft gevonden. Hij schrijft dus Nederlands in het kwadraat. Zijn verhalen vormen een prikkelend debuut, al is zijn procédé gekunsteld.

\section{De meestverkochte romans}

$\mathrm{Nu}$ - eindelijk - de romans. Bij mijn keuze laat ik me leiden door een aantal lijstjes: van de meestverkochte romans en romanschrijvers (op basis van de Top Tien in Vrij Nederland, 1985-1999 - zie bijlage 2) en van de beste romans, volgens het oordeel van een aantal kenners uit Vlaanderen en Nederland (bijlage 1).

De meestverkochte romanschrijver is - nog altijd - Maarten 't Hart (1944), in veel opzichten meteen de meest Hollandse in traditionele zin. Hij is immers bij uitstek de schrijver van het Hollandse polderlandschap, het op en top gecultiveerde groene grasland dat wij tot onze "natuur" rekenen. Zijn helden maken daar lange fiets- en schaatstochten en genieten 's zomers van de vogels. Hij beschrijft een calvinistische 
wereld, vol van dominees, ouderlingen en kerksplitsingen. Zijn helden zijn jongens of jonge mannen die met die wereld botsen en daarover vervolgens schuldgevoelens krijgen. 't Hart heeft inmiddels een lange reeks romans en verhalenbundels op zijn naam. Zijn beste werk speelt in of bij zijn geboorteplaats Maassluis; er heerst een spanning tussen aan de ene kant de kritiek op dat vervloekte gereformeerdendom en aan de andere kant heimwee naar de jeugd, toen tijdens de - vervelende kerkdienst af en toe de zon prachtig binnenviel door de gereformeerde kerkramen. Tot dat beste werk hoort bijvoorbeeld De jacobsladder (1986). In deze roman komt 't Hart met één van zijn verschrikkelijkste zwaar-gereformeerde personages, een man die twee van zijn kinderen heel gelovig naar de zelfmoord drijft en daarmee ook zijn gezin opblaast, maar - en dat is 't Harts schrijversprestatie - voor de lezer niettemin een beetje sympathiek blijft. Een andere uitschieter is Het woeden der gehele wereld (1993), waarin 't Hart zich in moderne trant, maar niet voor het eerst, op de rand van het detective-verhaal begeeft, en tegelijk, volgens een niet aflatende traditie in de moderne Nederlandse literatuur, de Tweede Wereldoorlog in zijn verhaal betrekt.

Meer dan voorheen is 't Hart in Nederland een publieke figuur geworden. Dat komt niet alleen door zijn schrijven, maar ook doordat hij bij verschillende gelegenheden in het openbaar optreedt in travestie, onder de naam Maartje 't Hart. Zijn uitgever verspreidt foto's van een opvallend jong ogende 't Hart, verfraaid met een aanlokkelijke vrouwenpruik en een lakjas. Natuurlijk weet hij dat dit hem in de aandacht brengt, maar zijn optreden als deeltijd-vrouw is toch geen goedkope stunt, maar berust op een authentieke verkleedobsessie, die meteen een veelbelovend thema vormt voor nog te schrijven werk.

Een andere literaire sensatie van de jaren negentig is de romancyclus "Het bureau" van J.J. Voskuil (geb. 1926): zo'n 5500 bladzijden in zeven sinds 1995 jaarlijks verschijnende delen. Pal voor Sinterklaas 2000 kwam het laatste. Deze boeken geven een precieze beschrijving van het leven op een cultureel-wetenschappelijk instituut, een kantoor waar de hoofdfiguur met weerzin vrijwel zijn hele arbeidzame leven doorbrengt. Absurde kanten van het wetenschappelijke kantoorleven krijgen ruim de aandacht. Rond "Het bureau" is in Nederland een cultus ontstaan: op de dag dat er een nieuw deel uitkwam (de uitgever maakte de datum ruim tevoren bekend) stonden er 's ochtends bij openingstijd kleine groepjes mensen bij de winkel klaar om hun nieuwe Voskuil aan te schaffen. Ze hadden bij hun werk een snipperdag opgenomen om diezelfde dag helemaal op de hoogte te komen van de nieuwste ontwikkelingen op "het bureau". 
Voskuil is een literaire fijnschilder die uitmunt in natuurlijke dialogen. De lezers geven hoog op over de herkenbaarheid van wat hij beschrijft. Uit Voskuils succes kun je opmaken dat de Nederlandse lezer ervan houdt om de ellende van zijn werk in zijn vrije uren rustig over te lezen. Net als Voskuils vorige boek, Bij nader inzien (1200 bladzijden, 1963, over het studentenleven), heeft "Het bureau" een ethisch thema. In allebei wordt de hoofdfiguur, Maarten Koning, beheerst door dezelfde vragen: hoe houd je schone handen?, hoe kun je je fatsoenlijk gedragen in een wereld beheerst door eigenbelang en roemzucht?

De heisa rond deze serie gaat verder dan die rijtjes vroege Voskuilianen bij de boekwinkel.1 De aandacht van lezers, onder wie journalisten, richtte zich op het "echte" bureau waar de schrijver Voskuil werkelijk gewerkt heeft. Er verschenen lijstjes "wie is wie in 'Het bureau'" en met Voskuils "echte" collega's kwamen er vraaggesprekken, waarbij de onuitgesproken vraag soms leek te zijn of deze brave mensen werkelijk de verachtelijke nitwits waren die Voskuil beschreven had. Het bureau had sinds 1995 een nieuwe directeur die dan ook in de eerste delen helemaal niet voorkwam, maar kennelijk zo bij de keel is gegrepen door het vooruitzicht dat hij in latere delen wel herkenbaar zou optreden, dat hij ontslag nam. Naar aanleiding van deze geschiedenis zijn critici en ingezonden-brievenschrijvers van leer getrokken met uitgesproken meningen over de vraag, in hoeverre de schrijver vrij is om zijn medemensen in literair werk te "gebruiken" door ze herkenbaar op te voeren, een debat dat in Zuid-Afrika doet denken aan Koos Prinsloo en het proefschrift van Riana Scheepers. Voor een helder standpunt kunnen we aankloppen bij de jonge sterauteur Arnon Grunberg, die beweerde: "Bij een roman telt alleen het resultaat".

Voskuil verkoopt geweldig, maar helemaal bovenaan de lijst staan toch romans over de twee ijzeren thema's van de moderne Nederlandse literatuur: de Tweede Wereldoorlog en Nederlands-Indië. De meestverkochte roman is De tweeling (1993) van Tessa de Loo (geb. 1946), dat op het bedaagde oorlogsthema een nieuwe kijk biedt. In deze roman over een vrouwelijke tweeling, geboren in 1916 (één meisje groeit in Nederland op en één in Duitsland), valt de nadruk namelijk nu eens op Duits leed. De Loo schreef een tendensroman, met als strekking: verzoening, in het bijzonder de bestrijding van de beruchte, zo langzamerhand dikwijls bête anti-Duitse houding in Nederland. Jonckheere (1996:81-91) heeft de actualiteit van dit boek voor Zuid-Afrika aangegeven.

1 "Alles" over Voskuil staat op http://huizen.dds.nl/ jdfvh/voskuil.html 
Meestverkochte roman op één na is Indische duinen (1994) van Adriaan van Dis. Van Dis was aanvankelijk bekend als schrijvende televisiepresentator, maar is inmiddels in de eerste plaats schrijver. De Indische problematiek van zijn boek blijkt uit de gezinssituatie van de hoofdfiguur, die behoort tot het milieu van de Indische repatrianten: Nederlanders, dikwijls ook Indo-Nederlanders, die na de Indonesische onafhankelijkheid in 1949 uit dat land naar Nederland "terugkeerden" (voor velen was van terugkeer feitelijk geen sprake omdat zij weliswaar van Nederlandse afkomst waren maar hun familie al generaties lang in Indië had gewoond). De hoofdfiguur is kort voor de repatriëring, dus in Indonesië, verwekt, maar wordt in Nederland geboren. Hij heeft geen Indonesische voorouders, maar tot het gezin horen ook twee halfzusjes uit een eerder huwelijk van de moeder. Haar eerste man was Indo-Nederlander, en de halfzusjes zijn dat dus ook. Moeder en zusjes zijn tijdens de oorlogsjaren (1942-1945) opgesloten geweest in Japanse kampen. Deze schokkende ervaring, en ook de slechte, ongastvrije ontvangst die Nederland de terugkerende landgenoten destijds bereid heeft, stempelen het gezinsleven en belasten dus ook de opgroeiende hoofdfiguur, die ook nog eens te maken krijgt met de moeilijkheden die zijn zussen als indo's ondervinden in de Nederlandse samenleving.

Hoewel Arthur Japin (geb. 1956) met De zwarte met het witte hart (1997, vertaald in het Frans, Duits, Engels, Deens, Noors, Spaans en Italiaans) op zijn eentje met veel verve het genre van de Nederlands-WestAfrikaanse literatuur uit de dood liet terugkeren, en Surinaamse en Antilliaanse schrijvers als Astrid H. Roemer (geb. 1947, zie Van Kempen, 1998), Tip Marugg (geb. 1923, zie Van Heerden, 1999) en Frank Martinus Arion (geb. 1936) hun eigen plaats hebben, blijft de betekenis van deze groep voorlopig toch achter bij de "Indische literatuur" (de Nederlandstalige letteren met betrekking tot Nederlands-Indië en Indonesië), die ruim vijftig jaar na de onafhankelijkheid van Indonesië almaar blijft doorbloeien. Tot de belangrijkste auteurs horen nog altijd Hella S. Haasse (geb. 1918), die aan haar veelzijdige oeuvre een grote Indische historische roman toevoegde: De heren van de thee (1992), en F. Springer (geb. 1932). In Springers werk is de hele twintigste-eeuwse "Indische" geschiedenis terug te vinden: het in veler herinnering paradijselijke Indië van voor 1942 (dat bij hem ook minder paradijselijke trekken toont), de Japanse kampen, de verwarde jaren 1945-1949, toen het Nederlandse leger opdracht kreeg de koloniale klok terug te zetten. Als één van de zeer weinigen heeft hij, in Bericht uit Hollandia (1962) en Schimmen rond de Parula (1966), geschreven over het allerlaatste restje van het Nederlands-Indische rijk: Nederlands Nieuw-Guinea, dat tenslotte na nóg een klein oorlogje en een serie waardeloze beloften aan de bewoners van het land, de Papoea's, in 1963 aan Indonesië is 
overgedragen. Tot Springers grote boeken horen Bougainville (1981), zijn saluut aan Multatuli, en Quissama (1985), geen Indische roman maar een verhaal dat zich afspeelt in Angola. Onder zijn recentste romans valt Bandoeng-Bandung (1993) op, de geschiedenis van een verraad. Een Nederlandse jongen krijgt in een kamp hulp van een IndoNederlandse klasgenoot, belooft als tegenprestatie hem te zullen meenemen naar Nederland maar verbreekt die belofte. Tientallen jaren later, als de stad Bandoeng op z'n Indonesisch Bandung is gaan heten, keert de Nederlander terug naar Indonesië en wordt met zijn oude vriend geconfronteerd. Het Nederlandse kwade geweten over het koloniale verleden komt in de reactie op deze roman op een heel vreemde manier naar voren: het kerngegeven dat de verrader Europeaan en de verradene Indo-Nederlander is, wordt in een gezaghebbend naslagwerk als het Lexicon van literaire werken domweg over het hoofd gezien (vgl. GiardKramer, 1997).

\section{De beste romans?}

Tenslotte: de tips van de kenners. Ik heb een aantal geleerden en critici van naam en faam gevraagd naar: "de vijf romans (verschenen na 1985) die in uw ogen van 'de recente Nederlandse roman' de beste indruk geven". In de vraagstelling zit een zekere dubbelzinnigheid, doordat "beste" zowel kan verwijzen naar de literaire kwaliteit als naar de representativiteit van de romans; niettemin waren veertien deskundigen zo vriendelijk om mij met een antwoord van dienst te zijn. Zoals altijd blijken de kenners het in veel opzichten met elkaar oneens, maar toch komt er een klein kopgroepje naar voren, bestaande uit een drietal werken: Mystiek lichaam van Frans Kellendonk (1951-1990), de romancyclus "De tandeloze tijd" van de al genoemde A.F.Th. van der Heijden (1951) en De ontdekking van de hemel (1992) van de oude meester Harry Mulisch (1927)2. Zoals altijd blijken de kenners het ook hevig oneens met de kopers. Alleen Mulisch onttrekt zich aan deze oude wet: als enige boek staat zijn Ontdekking hoog in allebei de lijsten.

\subsection{Frans Kellendonk}

De jong overleden schrijver Kellendonk behoorde in Nederland tot de eerste aids-slachtoffers van wie de homoseksualiteit bekend was. In Zuid-Afrika vergeleek Olivier (1997) zijn laatste roman, Mystiek lichaam, met verhalen van (alweer) Koos Prinsloo. In Nederland is Mystiek lichaam omstreden sinds de verschijning in 1986. Eenstemmigheid

2 http://www.mulisch.nl 
heerst over de literaire kwaliteit in beperkte zin - iedereen noemt het boek uitstekend geschreven - maar er bestaan heel verschillende oordelen over de gedachtenwereld van de roman. Aanvankelijk deed de vraag opgeld of Kellendonk een antisemitisch boek had geschreven (is in Nederland de Tweede Wereldoorlog eens níet het onderwerp, dan haalt de kritiek die er toch wel bij). In feite schrijft hij (onder meer) over het antisemitisme, en slaat het verschil van waardering hoofdzakelijk op de al of niet gevaarlijke manier waarop hij nare antisemitische oprispingen van zijn personages in zijn roman verwerkt.

De laatste jaren is Kellendonk met een literaire tentoonstelling, een televisieprogramma en boeken over zijn werk gevierd als klassieke schrijver. Tegelijk wordt zijn hele levensvisie door de tegendraadse criticus René Marres aan de kaak gesteld als oerconservatief en reactionair. Mystiek lichaam, waarvan de inhoud op z'n triviaalst kan worden samengevat als het verhaal over een homo die zichzelf waarschijnlijk aids aandoet, terwijl zijn zuster een gezin sticht, rust namelijk op een opvallende tegenstelling. Aan de positieve kant staan de heteroseksualiteit, het huwelijk, vruchtbaarheid, gemeenschapszin; aan de negatieve: een uit elkaar vallende, ongelovige samenleving, de "tegennatuurlijke" homoseksualiteit die isolement brengt en zelfs, via aids, de dood. Maar wie het zo uitdrukt, ziet een belangrijke nuance over het hoofd: ook over de op het eerste gezicht positieve elementen hangt een onwerkelijke, bijna griezelige sfeer, een sfeer van akeligheid. Ook het nieuwe gezin is bepaald een naargeestige affaire. De lezer weet niet goed wat hij ervan moet denken: gaat het hier om radicale ironie? De conclusie moet zijn dat Kellendonk verwarring zaait doordat hij in de eerste plaats uitdrukking geeft aan eigen vertwijfeling.

\subsection{Harry Mulisch}

Harry Mulisch verklaart in Mijn getijdenboek: "ik heb de oorlog niet 'meegemaakt', ik ben de Tweede Wereldoorlog" (1975:64). Hij verwijst ermee naar zijn ouders. Zijn vader is afkomstig uit Midden-Europa (Mulisch poseert een enkele keer als de eerste tweede-generatie-immigrant van de Nederlandse literatuur) en werkte tijdens de Duitse bezetting in Nederland voor de Duitsers, bij de bank die de roof van joodse bezittingen organiseerde; na de bevrijding is hij gevangen gezet. Mulisch' moeder was daarentegen zelf joods. Mulisch is één van de Nederlandse schrijvers over de oorlog; zijn werk is in dit opzicht vast verbonden met de werkelijkheid. Maar er is ook een andere Mulisch: de jongen die de rector van het Christelijk Lyceum in Haarlem, dr. J. van der Elst, op 9 maart 1944 een "onderaards kletser" noemde (Mulisch, 1975: 82-83). Verwante klachten komen terug in de kritiek. Mulisch krijgt het 
verwijt dat hij onrealistisch, intellectualistisch en hermetisch schrijft, of ook wel: filosofisch in de slechte zin van het woord. Maar ook de lof dat hij al schrijvend magie bedrijtt, doordat hij verbindingen legt die bij een zuiver rationele benadering verborgen blijven. Hij wendt klassieke en christelijke mythen aan om bij zijn lezer de beoogde vonken te laten overspringen, maar neemt soms zelfs zijn toevlucht tot taalspelletjes. Zelf noemt hij schrijven alchemie: een vorm van "wetenschap" waarbij de onderzoeker niet objectief terzijde staat maar juist direct met zijn stof verbonden is. Het goud dat de oude alchemisten wilden maken, is voor de schrijver vanzelfsprekend het boek dat hij onderhanden heeft. Is Mulisch als magisch-mythische denker beslist omstreden, zijn hantering van de taal en zijn rijke fantasie worden bijna altijd toegejuicht. Bij De ontdekking van de hemel, een boek van tegen de duizend bladzijden, oogstte hij vrijwel alleen applaus, ook in de internationale kritiek (de roman verscheen in het Frans, Duits, Engels en Italiaans). In Nederland zijn inmiddels al drie boeken over De ontdekking van de hemel uitgekomen (Haan \& Aertsen, z.j.; De Rover, 1995; Steenhuis, 1995). Schoonheim (1995) vervaardigde een concordantie.

Voor een klein deel bevat het boek hemelse taferelen: zoals in bepaalde middeleeuwse literatuur treden engelen op. Zij breken zich er het hoofd over dat de mens tot almaar meer in staat blijkt. Hij is door de techniek binnengedrongen in wat vroeger het uitsluitende domein was van de hemelse macht. Door die ontwikkeling is het de mens gaan ontbreken aan ontzag: ontzag voor God, maar daarmee meteen ontzag in het algemeen. De engelen zijn bang dat zowel de mens als de hemel hieraan op den duur ten onder gaan, en proberen in te grijpen. Het is duidelijk dat Mulisch grote onderwerpen aanpakt: de positie van de mens, de hachelijke positie van de cultuur. De samenleving dreigt uit elkaar te vallen doordat de mythen verloren zijn gegaan. Vroeger meende de mens goden nodig te hebben, bedacht en eerbiedigde ze. $\mathrm{Nu}$ vindt hij de goden overbodig, maar begrijpt volstrekt niet wat er ontbreekt als hij alle geloof overboord zet (vgl. Kralt, 1997). Misschien zou de kunst met nieuwe mythen het tekort voor de ongelovige kunnen aanvullen: al in de jaren vijftig karakteriseerde de criticus H.A. Gomperts (z.j.:166) de jonge Mulisch tenslotte als schepper van mythen. Hoe dan ook: Mulisch is in De ontdekking van de hemel op zijn best doordat hij zijn "zware" stof weet te verlichten in een speels verhaal, in zinrijk amusement.

Tegenover het hemelse staat een veel omvangrijker aards verhaal, dat zich in hoofdzaak afspeelt in het Nederland van de jaren 1967-1985. De aanvankelijke hoofdfiguren zijn twee boezemvrienden, een sterren- en een taalkundige, die sterk doen denken aan Mulisch zelf en een vriend 
van hem, de schaker en schrijver J.H. Donner. De sterrenkundige staat op het punt, bij zijn diepgaande onderzoek van het heelal de hemel te ontdekken, maar op het moment dat hij door een beslissend nieuw inzicht de hemel binnen handbereik krijgt, komt hij om het leven, door toedoen van de engelen. Er is inmiddels een zoon geboren, maar het is onzeker wie van de twee de vader is, de taal- of de sterrenkundige. Die zoon is duidelijk voorbestemd voor grote dingen, net als die andere Zoon van wie de Vader onbekend was, en onderneemt die ook; het zijn alweer de engelen die hem zonder dat hij dat weet inspireren, maar aan het slot van de roman zijn hun zorgen alleen maar toegenomen - er is nog maar één engel die de mensheid niet helemaal heeft opgegeven.

\subsection{A.F.Th. van der Heijden}

Tenslotte de schrijver waarmee ik begonnen ben: Van der Heijden, en zijn cyclus "De tandeloze tijd". Alweer een cyclus, maar van ander karakter dan die van Voskuil. Vormt "Het bureau" één doorlopend verhaal dat bij de verschijning van het eerste deel al helemaal voltooid was, "De tandeloze tijd" is in zijn compositie en publicatiegeschiedenis heel wat grilliger. Zelfs klinkt van tijd tot tijd in de kritiek de vraag, of de auteur zijn cyclus nog wel in de hand heeft. Hoe dit ook zij, Van der Heijden heeft behalve voor literatuur ook veel gevoel voor publiciteit en weet zelfs met loze beloften over te verschijnen vervolgdelen zijn lezers zijn ban te houden.

Het begin ligt in 1983, de tot nu toe laatste delen stammen uit 1996. Aanvankelijk had de schrijver een kort proloogdeel (De slag om de Blauwbrug) en een daarop volgende trilogie aangekondigd, maar na de proloog en de eerste twee delen (Vallende ouders, 1983, De gevarendriehoek, 1985) bleef het afsluitende derde jarenlang uit. Van der Heijden maakte het intussen almaar mooier doordat hij opeens kwam met een vierde deel, Advocaat van de hanen (1990), en ook nog met een dun boekje dat als "intermezzo" werd aangeduid (Weerborstels, 1992). Dit diende als boekenweek-geschenk, zodat ook de enkeling die nog niet van "De tandeloze tijd" gehoord had, wel moest merken waarmee Van der Heijden bezig is. In 1996 verscheen dan eindelijk het dertien jaar tevoren aangekondigde derde deel; de verrassing school er nu in dat het bleek uitgegroeid tot twee delen van bij elkaar zo'n 1500 bladzijden (Het hof van barmhartigheid, Onder het plaveisel het moeras). Van der Heijden hield het balletje hoog door meteen een vijfde deel aan te kondigen. Anno 2001 trekt hij opnieuw de aandacht met een verse reclamecampagne: hij heeft - à la Reve - zijn naam ingekort tot "A.F.Th." en begint niets minder dan een nieuwe romancyclus. Wie van 
al Van der Heijdens toeren niets wil missen, melde zich via www.afth.nl via e-mail krijgt men dan de allernieuwste nieuwtjes.

"De tandeloze tijd" is maar gedeeltelijk een vervolgserie. Men vergelijkt Van der Heijdens werk wel met "Les Rougon-Macquart", de cyclus van Emile Zola van het eind van de negentiende eeuw. Zola schreef twintig romans, die in hoofdzaak thematisch verbonden zijn, al komen er wel personages uit vroegere delen in latere delen terug. Volgens de ondertitel bevat "Les Rougon-Macquart": een "histoire naturelle et sociale d'une famille sous le Second Empire", waarbij dat Tweede Keizerrijk verwijst naar het Frankrijk van 1852-1870. Zola wil dus een sociale geschiedenis in romanvorm schrijven, waarbij hij als naturalist een "echte werkelijkheid" onthult achter de schone schijn die de lezer tegemoetstraalde in het werk van idealistischer collega's. Van der Heijden ziet men wel als de Zola van het Nederland van de jaren zeventig en tachtig, vooral het Nederland van opstandig, half misdadig Amsterdam; de politie vecht met krakers om gekraakte huizen te ontruimen; drugsverslaving en drugshandel zijn aan de orde van de dag, net als racisme, kinderhandel en moord. Het gaat te ver om hem bij het negentiende-eeuwse naturalisme in te lijven, maar een idealistische visie ontbreekt helemaal. Wie zijn kinderen wil afhouden van een bezoek aan het verdorven Amsterdam zou op het idee kunnen komen, ze een boek van Van der Heijden cadeau te doen - al is bij dergelijke pedagogische foefjes het omgekeerde effect nooit uit te sluiten.

Er zijn ook veel verschillen met het werk van Zola. De terugkerende personages spelen bij Van der Heijden een belangrijker rol en er is zelfs voor de cyclus een hoofdfiguur aan te wijzen: de student filosofie, later drugsverslaafde autokraker Albert Egberts. Het aspect "familiegeschiedenis" is bij Zola belangrijk, doordat hij aan allerlei familieleden overeenkomstige karaktertrekken toekent om op die manier de negentiendeeeuwse erfelijkheidsleer te illustreren. Bij Van der Heijden is eerder sprake van een gezinsgeschiedenis want we maken vooral kennis met Egberts' naaste familie, op een manier die aan het geheel een autobiografische suggestie geeft. Egberts is een Brabantse arbeiderszoon, lid van de eerste generatie arbeiderskinderen die op vrij grote schaal de kans kreeg om verder te studeren. Hij doet kandidaatsexamen filosofie aan de Katholieke Universiteit in Nijmegen en verkast dan naar Amsterdam. In "De tandeloze tijd" spelen terugblikken naar zijn Brabantse jeugd een grote rol, waarbij opnieuw duistere tinten de overhand hebben. Zijn vader is alcoholist; het is onduidelijk of Albert een kind van zijn officiële vader is of van een oom. Ook de Tweede Wereldoorlog en het verlies van Nederlands-Indië spelen weer een rol, doordat de betreffende oom 
voor de Duitsers gevochten heeft, en zijn vader in de jaren 1945-1949 als vrijwilliger in het Nederlandse leger in Indonesië diende.

Het is duidelijk Van der Heijdens literaire bestemming om in de beeldende taal die als één van zijn handelsmerken geldt, een zwaar accent te plaatsen op de duistere kanten van onze samenleving, zozeer dat men zijn werk, net als Mystiek lichaam overigens, kan omschrijven als grotesk. Zelf grijpt hij dit aan om te beklemtonen dat hij geen realist wil zijn: hij streeft (in tegenstelling tot Zola) volstrekt niet naar objectiviteit, maar tekent een beeld dat opzettelijk subjectief is. Maar tegelijk heeft hij weer wel de bedoeling om langs deze weg bepaalde wezenlijke karaktertrekken van de mens aan het licht te brengen en te verduidelijken. $\mathrm{Al}$ is hij geen broer van Zola, dan toch wel een neefje.

Realistisch zijn zijn verwijzingen naar historische gebeurtenissen, zoals naar de dood van de kraker Hans Kok in een Amsterdamse politiecel of naar een bepaalde moordzaak, maar vervolgens voegt hij aan die gebeurtenissen en aan de erbij betrokken personen allerlei totaal onhistorische trekken toe. Niet alle lezers hebben van Van der Heijdens subtiele verhouding tot het realisme voldoende begrip, vooral niet als Van der Heijden hun eigen geschiedenis tot uitgangspunt kiest. Zo bezorgde de vriend van een in "De tandeloze tijd" minder gunstig "afgebeelde" vrouw de schrijver ooit een blauw oog; de discussie rond J.J. Voskuil en Koos Prinsloo (en Johannes Kerkorrel) duikt dus ook op bij Van der Heijden. Journalisten beschuldigden hem van plagiaat omdat hij zich geïnspireerd had op affaires die zij eerder hadden beschreven; Amsterdamse krakers probeerden de verfilming van Advocaat van de hanen te dwarsbomen omdat de schrijver van hun strijd geen goed beeld zou geven.

Het minst realistische aspect wordt aangestipt in de titel van de cyclus. leder weet immers dat de reële tijd niet tandeloos is, maar ons overlevert aan aftakeling en dood. Zoals ook in Het leven uit een dag blijkt, behoort de tijd tot de obsessies van Van der Heijden. In de compositie van zijn cyclus zoekt hij een middel om de tijd tóch tandeloos te maken, en wel door een duizelingwekkend gecompliceerde chronologie. Hij onderbreekt zijn verhaal met een herinnering van één van de figuren, die leidt naar een bladzijdenlange "flash back". Binnen die terugblik begint een ander spannend verhaal, en daarbinnen nóg één. Ondertussen staat de tijd in het hoofdverhaal stil, en is dus tandeloos. De personages filosoferen over vergelijkbare mogelijkheden om de tijd tandeloos te maken door te "leven in de breedte": Albert Egberts wil allerlei indrukken en flitsen van indrukken razendsnel door zich heen laten gaan om op die manier een groot deel van zijn leven te ervaren in één moment. 
Ondanks dit oorspronkelijke idee van Egberts moet ik besluiten dat alle drie door de kenners uitverkoren werken een zwart beeld van de samenleving vooropstellen; alle drie zijn ook verbonden met actuele maatschappelijke problemen, zoals aids, drugs, verzakelijking, geweld en misdadigheid. Waarschijnlijk zal de literatuurhistoricus van het jaar 2100 vaststellen dat de uit elkaar vallende samenleving de obsessie van het Nederland van het eind van de twintigste eeuw was. "Oplossingen" bieden de schrijvers waarschijnlijk geen van drieën, althans niet in de vorm van politieke, wetenschappelijke of religieuze ideeën die ons er bovenop zouden kunnen helpen. Het werk van Kellendonk bevat wel aangrijpingspunten in die richting, maar onduidelijkheid is hun duidelijkste karaktertrek. Bij Mulisch, de minst zwaarwichtige van de drie, klinkt het echte alternatief het duidelijkst door: het verlies van de mythe dat hij signaleert, wordt misschien gecompenseerd in de kunst, dus onder meer in het werk van Mulisch zelf.

\section{Besluit}

Ik zei al: de internationalisering brengt een vruchtbare verbreding van de Nederlandse literatuurkritiek mee. Met de critici heeft de schrijver niet langer altijd zijn culturele achtergrond gemeen. Reactie uit vreemde hoek, Duitse, Franse, Amerikaanse en Poolse kritische reactie op Nederlandse literatuur is heilzaam, maar dit geldt vooral voor kritiek uit Zuid-Afrika. Een voortgaande levendige Zuid-Afrikaanse reactie op de Nederlandse literatuur is misschien een Zuid-Afrikaans, maar in elk geval een Nederlands belang. De Zuid-Afrikaanse kritiek beschikt immers aan de ene kant traditioneel over een grote kennis van Nederland en heeft, voorzover die kennis eens te kort schiet, noodzakelijke documentatie bij de hand. Bovendien kunnen de Zuid-Afrikanen die Afrikaans kennen, Nederlands lezen, zeer veel beter dan Duitsers of Polen. Ze zitten dus niet vast aan wat toevallig beschikbaar komt in vertaling. Tegelijk maken aan de andere kant de diepgaande verschillen tussen de Nederlandse en Zuid-Afrikaanse samenleving de Zuid-Afrikaan op Nederlands gebied behalve intimus ook vreemdeling. Op een terrein dat zowel vertrouwd als nieuw is, valt hem op wat niemand anders ziet.

Daarom is een actueel overzicht vanuit Zuid-Afrikaans perpectief een zegen voor de Nederlandse literatuur. Daarom sluit ik namens de $\mathrm{Ne}-$ derlandse letterkunde mijn eerbewijs voor prof. Jacques van der Elst af met een beroep op hem: beste Jacques, een vernieuwde uitgave van je Momente van die Nederlandse letterkunde is broodnodig. 


\section{Bijlage 1}

\section{Recente romans, hoog aangeschreven bij critici en geleerden}

Gevraagd op 23 maart 1999: "de vijf romans die in uw ogen van 'de recente Nederlandse roman' de beste indruk geven", verschenen na 1985.

Aan: eenentwintig personen die blijk geven van grote belangstelling voor hedendaagse romans, vijftien Nederlanders en zes Vlamingen, vijftien mannen en zes vrouwen.

Antwoord gekregen van: veertien daarvan, negen Nederlanders en vijf Vlamingen, dertien mannen en een vrouw: Ton Anbeek, Robert Anker, Jos Borré, Hugo Bousset, Hugo Brems, T. van Deel, Jaap Goedegebuure, Hans Goedkoop, Arnold Heumakers, A.M. Musschoot, Cyrille Offermans, Frans Ruiter, Rob Schouten, Bart Vervaeck.

Drie van hen konden niet anders dan zes romans noemen. Zo zijn er drieënzeventig stemmen uitgebracht, en wel op:

A.F.Th. van der Heijden: de onvoltooide cyclus "De tandeloze tijd" 3, de delen Vallende ouders (1983) 1, De Gevarendriehoek (1985) 1, Advocaat van de hanen 4. Als je alles bij elkaar telt: 9.

Harry Mulisch: De ontdekking van de hemel 8

$\begin{array}{ll}\text { Frans Kellendonk: Mystiek lichaam } & 7\end{array}$

Thomas Rosenboom: Gewassen vlees 5

Hugo Claus: De geruchten 4

Nicolaas Matsier: Gesloten huis $\quad 4$

Charlotte Mutsaers: Rachels rokje 4

J.J. Voskuil: de (in 1999 nog onvoltooide) cyclus "Het bureau" 3

Paul de Wispelaere: Het verkoolde alfabet 3

Stefan Hertmans: Naar Merelbeeke 2

Monika van Paemel: Vermaledijde vaders (1985) 2 


\section{Eén stem voor:}

Robert Anker: Vrouwenzand; Walter van den Broeck: Het leven na beklag; Jeroen Brouwers: De zondvloed; Hugo Claus: Belladonna en Onvoltooid verleden; Adriaan van Dis: Indische duinen; Renate Dorrestein: Ontaarde moeders; Anna Enquist: Het geheim; Kees 't Hart: Blauw Curaçao; A.F.Th. van der Heijden: Het leven uit een dag; Gerrit Krol: Middletons dood; Hedda Martens: Een naald op het water, Marcel Möring: In Babylon; Nelleke Noordervliet: Het oog van de engel; Connie Palmen: De wetten; Leo Pleysier: De gele rivier is bevrozen en Wit is altijd schoon; K. Schippers: Poeder en wind en Vluchtig eigendom; Willem van Toorn: Een leeg landschap; Jacq Vogelaar: De dood als meisje van acht; Joost Zwagerman: Gimmick.

\section{Bijlage 2}

Meestverkochte recente romans (verschenen na 1985). Bron: de jaaroverzichten "Best verkocht" (van de vijftig in Nederland meestverkochte boeken, rubriek "fictie") 1986-1998, zoals afgedrukt in Vrij Nederland. Een eerste plaats geeft vijftig punten, een tweede negenenveertig, een vijftigste één. Over 1999 heeft V.N. geen overzicht gepubliceerd.

Tessa de Loo: De tweeling 152

Adriaan van Dis: Indische duinen 131

Harry Mulisch: De ontdekking van de hemel 127

Hella S. Haasse: Heren van de thee 115

Connie Palmen: De vriendschap 104

Anna Enquist: Het geheim 93

Lulu Wang: Het lelietheater $\quad 80$

Maarten 't Hart: De jacobsladder $\quad 77$

Hugo Claus: De geruchten $\quad 76$

Joost Zwagerman: De buitenvrouw 73

Helga Ruebsamen: Het lied en de waarheid 72

Margriet de Moor: De virtuoos $\quad 69$

Maarten 't Hart: Het woeden der gehele wereld 65

Willem Frederik Hermans: Een heilige van de horlogerie 64

Arnon Grunberg: Blauwe maandagen 63

En verder op de lijst onder andere: 
Nicolaas Matsier: Gesloten huis $\quad 44$

Thomas Rosenboom: Gewassen vlees $\quad 40$

A.F.Th. van der Heijden: Het hof van barmhartigheid ("De tandeloze tijd" 3a)

A.F.Th. van der Heijden: Het leven uit een dag 36

F. Springer: Bandoeng-Bandung 36

J.J. Voskuil: Plankton ("Het bureau" 3) 35

Tip Marugg: De morgen loeit weer aan 32

Henk van Woerden: Moenie kyk nie 26

Frans Kellendonk: Mystiek lichaam 15

Arthur Japin: De zwarte met het witte hart 3

In Nederland meestverkochte schrijvers (optelling van de lijst hierboven, aangevuld met de onvermelde recente romans die 1-60 punten haalden; achter de naam staat tussen haakjes het aantal romans dat punten bijdroeg)

Maarten 't Hart (7) 326

Tessa de Loo (3) $\quad 274$

Harry Mulisch (4) 274

Renate Dorrestein (6) 245

A.F.Th. van der Heijden (6) 240

Hella S. Haasse (4) 230

Connie Palmen (3) 201

Adriaan van Dis (2) 186

Willem Frederik Hermans (4) 184

Leon de Winter (5) 183

$\begin{array}{ll}\text { Margriet de Moor (3) } & 137\end{array}$

En verder op de lijst onder andere:

F. Springer (3) 85

J.J. Voskuil (4) 75

Bibliografie

Anbeek, Ton. 1999. De roman in de eenentwintigste eeuw. Terug naar de bron? Literatuur, 16(1):2-10, januari-februari. 
Boenink, Marianne. 1997. Boeken met een boodschap. Literatuur en normatieve oordeelsvorming. Krisis, tijdschrift voor filosofie, 68, herfst.

Bootsma, Esther. 2000. Mbeki's fout hoort investeerders niet te stuiten. Vraaggesprek met Carl Niehaus. Trouw, oktober, 21.

De Rover, Frans. 1995. Harry Mulisch ontdekt: over Harry Mulisch en "De ontdekking van de hemel". Amsterdam : Bezige bij.

Etty, Elsbeth. 1999. Lulu's luierseks. NRC Handelsblad, november, 20.

Giard-Kramer, Ina. 1997. Bandoeng-Bandung. Lexicon van literaire werken. Groningen : Wolters-Noordhoff. Aan dit losbladige werk toegevoegd in februari.

Gomperts, H.A. z.j. Mythen en legenden van Harry Mulisch. In: Gomperts, H.A. Intenties 2. Amsterdam : Meulenhoff. p. 166-195. In: Het Parool, 1953-1962.

Grunberg, Arnon. 1997. Bij een roman telt alleen het resultaat. NRC Handelsblad, juni, 28.

Grunberg, Arnon. 1998. Bij een roman telt alleen het resultaat. De polemiek over Het bureau van J.J. Voskuil. In: Grunberg, Arnon. De troost van de slapstick. Amsterdam : Nijgh \& Van Ditmar. p. 137-152.

Haan, Wim \& Aertsen, Jan A. z.j. Mulisch en de wetenschap: naar aanleiding van "De ontdekking van de hemel". Kampen : Kok.

Jonckheere, W.F. 1996. Een dilemma van percepties. De tweeling van Tessa de Loo. T. N \& A, Tydskrif vir Nederlands en Afrikaans, 3(1):81-91, Junie.

Knulst, Wim \& Kraaykamp, Gerbert. 1996. Leesgewoonten. Een halve eeuw onderzoek naar het lezen en zijn belagers. Het culturele draagvlak 2. Rijswijk : Sociaal \& Cultureel Planbureau.

Kralt, P. 1997. De ontdekking van de hemel. Lexicon van literaire werken. Groningen : Wolters-Noordhoff. Aan dit losbladige werk toegevoegd in november.

Marres, René. 1998. De radicale boodschap van Kellendonks Mystiek lichaam. In: Marres, René. Zogenaamde politieke incorrectheid in Nederlandse literatuur. Leiden : Internationaal forum voor Afrikaanse en Nederlandse taal en letteren. p. 103-119.

Mulisch, Harry. 1975. Mijn getijdenboek. Amsterdam : Landshoff.

Olivier, Gerrit. 1997. Frans Kellendonk, Koos Prinsloo en de dood "oprecht geveinsd". T.N \& A, Tydskrif vir Nederlands en Afrikaans, 4(2):234-249, April.

Ramdas, Anil. 1997. Niemand heeft oog voor het vreemde. Moedwil en kwade trouw bij blanke schrijvers. NRC Handelsblad, maart, 14.

Scheepers, Adriana Wilhelmina. 1997. Die verhouding tussen outobiografiese feit en fiksie in die kortverhaaloeuvre van Koos Prinsloo. (Ph.D.-proefskrif Universiteit van Kaapstad.) Handelseditie Die skrywer en sy geskryfdes. 1998. Kaapstad : Tafelberg.

Scheffer, Paul. 2000. Het multiculturele drama. NRC Handelsblad, januari, 29. Met uitvoerige discussie op www.nrc.nl/w2/Lab/Multicultureel/inhoud.html

Schoonheim, Justus. 1995. Een concordantie op Harry Mulisch' De ontdekking van de hemel. Derde druk. Leiden : Schoonheim.

Steenhuis, Peter Henk. 1995. Alles is altijd uit de Bijbel: schriftuurlijke verwijzingen in De ontdekking van de hemel. Amsterdam : Bezige bij.

Tesser, P.T.M., Merens, J.G.F., Van Praag, C.S. \& ledema, J. 1999. Rapportage minderheden 1999: positie in het onderwijs en op de arbeidsmarkt. Den Haag: Sociaal \& Cultureel Planbureau/Elsevier.

Van der Elst, J., Ohlhoff, C.H.F. \& Schutte, H.J. (red.) 1988. Momente in die Nederlandse letterkunde. Pretoria-Kaapstad : Academica. 
Van Heerden, Etienne. 1999. Die geding met die geheue: kontemporêre fiksie se bydrae tot teoretiese besinnings oor die historiografie.T. $N \& A$, Tydskrif vir Nederlands en Afrikaans, 6(1):2-18, Junie.

Van Kempen, Michiel. 1998. De onuitwisbare kenmerken van de zwarte stem. Over de stijl van Astrid H. Roemer. T. $N \&$ \& , Tydskrif vir Nederlands en Afrikaans, 5(1):21-39, Junie.

Zwagerman, Joost. 1997. Literatuur als inloopcentrum. NRC Handelsblad, maart, 28.

\section{Kernbegrippen:}
A.F.Th. van der Heijden
F. Springer
Frans Kellendonk
Harry Mulisch

Nederlandse literêre wêreld na 1985; aspekte van

populêrste Nederlandse romans na 1985

\section{Key concepts:}
A.F.Th. van der Heijden)
Dutch literary scene after 1985; aspects of
F. Springer
Frans Kellendonk
Harry Mulisch
most popular Dutch novels after 1985 